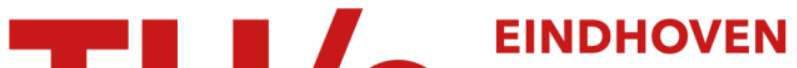

\section{Scaling and particle size optimization of mass transfer in gas fluidized beds}

Citation for published version (APA):

Lare, van, C. E. J., Piepers, H. W., \& Thoenes, D. (1990). Scaling and particle size optimization of mass transfer in gas fluidized beds. Chemical Engineering Science, 45(8), 2211-2217. https://doi.org/10.1016/00092509\%2890\%2980097-X, https://doi.org/10.1016/0009-2509(90)80097-X

DOI:

10.1016/0009-2509\%2890\%2980097-X

10.1016/0009-2509(90)80097-X

Document status and date:

Published: 01/01/1990

\section{Document Version:}

Publisher's PDF, also known as Version of Record (includes final page, issue and volume numbers)

\section{Please check the document version of this publication:}

- A submitted manuscript is the version of the article upon submission and before peer-review. There can be important differences between the submitted version and the official published version of record. People interested in the research are advised to contact the author for the final version of the publication, or visit the $\mathrm{DOI}$ to the publisher's website.

- The final author version and the galley proof are versions of the publication after peer review.

- The final published version features the final layout of the paper including the volume, issue and page numbers.

Link to publication

\section{General rights}

Copyright and moral rights for the publications made accessible in the public portal are retained by the authors and/or other copyright owners and it is a condition of accessing publications that users recognise and abide by the legal requirements associated with these rights.

- Users may download and print one copy of any publication from the public portal for the purpose of private study or research.

- You may not further distribute the material or use it for any profit-making activity or commercial gain

- You may freely distribute the URL identifying the publication in the public portal.

If the publication is distributed under the terms of Article $25 \mathrm{fa}$ of the Dutch Copyright Act, indicated by the "Taverne" license above, please follow below link for the End User Agreement:

www.tue.nl/taverne

Take down policy

If you believe that this document breaches copyright please contact us at:

openaccess@tue.nl

providing details and we will investigate your claim. 


\title{
SCALING AND PARTICLE SIZE OPTIMIZATION OF MASS TRANSFER IN GAS FLUIDIZED BEDS.
}

\author{
C.E.J. VAN LARE, H.W. PIEPERS and D. THOENES \\ Eindhoven University of Technology \\ Department of Chemical Engineering \\ Laboratory of Chemical Process Technology \\ P.o. Box 513, $5600 \mathrm{MB}$, Eindhoven, The Netherlands.
}

\begin{abstract}
.
Cunversion was measured in a gas fluidized bed, using the decompusition of ozulle as a mudel reaction. The results were expressed in terms of the height of a mass transfer unit.

Mass transfer data from our own experiments and a large number of literature data were analyzed. We found a Scaling parameter $S$, that could describe all experiments. This Scaling parameter can be helpful in scale up. For A type powders, the height of a mass transfer unit was shown to rise with increasing particle size, using $\mathbf{S}$ as reference.
\end{abstract}

\section{KEYWORDS}

Scale up; Fluidization; Particle size; Mass transfer; Chemical Reaction; Residence time distribution; Scaling parameter.

\section{INTRODUCTION}

Scale up is essentially the target for all investigations concerning gas fluidized beds: a method has to be found for predicting the conversion of a gas fluidized bed, under given circumstances. A very important factor that determines the conversion, is the mass transfer from the bubble phase to the dense phase.

The influence of the average particle size $d_{p}$ on the mass transfer is an important, but still not sufficiently investigated factor. Based on the theory of Sit and Grace (1978), we estimated the height of a mass transfer unit $H_{k}$ with increasing particle size and constant bed height, bed diameter and $U / U_{m f}$-ratio. $H_{k}$ was found to increase for $A$ and small $B$ powders (according to the classification of Geldart (1973)) and found to decrease for the large $B$ and $D$ type powders, with a maximum in between. This was confirmed by measurements of Borodulya et al. (1981). They performed experiments with a single bubble bed. However, hydrodynamics, and therefore mass transfer, are completely different in a freely bubbling bed.

Particle size influences a lot of other parameters. This means that it is impossible to simply determine the influence of $d_{p}$ on the height of a mass unit $H_{k}$, by measuring $H_{k}$ with several particle sizes. It is neccesary to find a factor that holds for all fluidized beds. Then it also should be possible to use this parameter as a tool in scale up. This work describes experimental work and analyses, concerning a lot of literature data, to abtain this parameter. For A/B powders the influence of $\mathbf{d}_{\mathbf{p}}$ on $\mathbf{H}_{\mathbf{k}}$ was determined.

\section{MODEL DESCRIPTION}

The model of Van Deemter (1961) was used to analyze the data. The fluidized bed is divided into two phases: the bubble phase in ideal plug flow and the dense phase in plug flow with axial dispersion.

Based on calculations and work of Van Swaaij and Zuiderweg (1972) we neglected the dispersion term for the dense phase. For $A$ and $B$ powders most of the gas enters the bed in the bubble phase, because $U \gg U_{m f}$. Then it can easily be derived that the following holds (Van Swaaij and Zuiderweg, 1972): 


$$
\frac{C_{e}}{C_{f}}=\exp \left(-N_{t}\right), \text { with } \frac{1}{N_{t}}=\frac{1}{N_{k}}+\frac{1}{N_{r}}
$$

From equation (1), known number of reaction units $N_{r}$ and measured conversion, the total number of units $N_{t}$ and the number of mass transfer units $N_{k}$ can be calculated.

\section{EXPERIMENTAL}

For our experiments the decomposition of ozone was chosen as a model reaction, because it is a first order reaction and process control is relatively simple.

The catalyst was quartz sand, coated with iron oxide. The properties of the catalyst are listed in table 1.

Table 1. Properties of catalyst used with experiments.

\begin{tabular}{|llc|}
\hline mean si eve particle size & $d_{32}$ & $67 \mu \mathrm{m}$ \\
particle density & $P_{\mathrm{p}}$ & $2590 \mathrm{~kg} / \mathrm{m}^{3}$ \\
minimum fluidization velocity & $U_{\mathrm{mf}}$ & $0.6 \mathrm{~cm} / \mathrm{s}$ \\
bed porosity & $\varepsilon_{\mathrm{mf}}$ & 0.55 \\
wt $7 \mathrm{Fe}$ & & 0.33 \\
\hline
\end{tabular}

Reaction rates were determined in a fixed bed reactor. The reaction was found to be first order with an activation energy of about $109 \mathrm{~kJ} / \mathrm{mole}$. This is of the same order as was found in previous investigations. Conversion experiments were performed in a fluid bed reactor with varying bed temperature and superficial velocity. Bed diameter was $10 \mathrm{~cm}$ and bed height was about 40 crn. A porous plate distributor was used. More detailed information can be found elsewhere (van Lare, 1990).

At low $k_{r}$. values the system is reaction rate controlled (I). which means that $N_{t} \approx N_{r}$. This implies that large $N_{k}$ and small $H_{k}$ values will be found. In this region it is also difficult to obtain accurate $H_{k}$ values, due to experimental error. Once the mass transfer controlled region is reached (II), $H_{k}$ will become constant, unti] accelerated mass transfer occurs (III). This is completely comparable with fixed beds. Indeed we found this trend (fig 1), but we did not reach region (III).

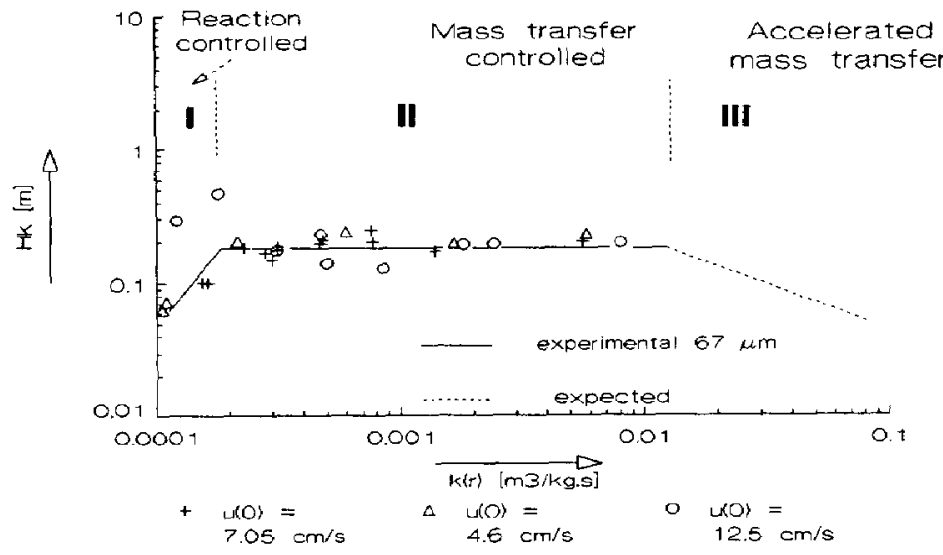

fig. $1 H_{k}$ values as a function of $k_{r}(67 \mu \mathrm{m}$ catalyst, experimental $)$ 
From literature it is known that region III indeed occurs. Figure 1 also shows that the influence of superficial velocity is rather small for these particles, probably due to the small $U_{m f}$ value. A $H_{k}$ value of about $18 \mathrm{~cm}$ was found.

\section{DATA ANALYSIS}

The process parameters, that were taken into account, were divided into three main groups:
a) particle properties: $d_{p}, \rho_{p^{\prime}} U_{m f}, \varepsilon_{m f}$.
b) gas properties: $\mu_{g}, D_{g}, P_{g}$
c) reactor dimensions and external influences: $U, H, D, H_{k}, N_{\Gamma^{\prime}}$ internals, distributor etc.

Data taken from the papers listed in table 2, were used for the analysis.

The values for $H_{k}$ were calculated from the given data and from the figures, presented in the papers. If not given, $\mu_{g}, D_{g}$ and $\rho_{g}$ were estimated from Perry's Handbook (1973). Ocassionally some particle properties had to be estimated also. More detailed information can be found elsewhere (van Lare, 1990).

Table 2. List of papers used for data analysts.

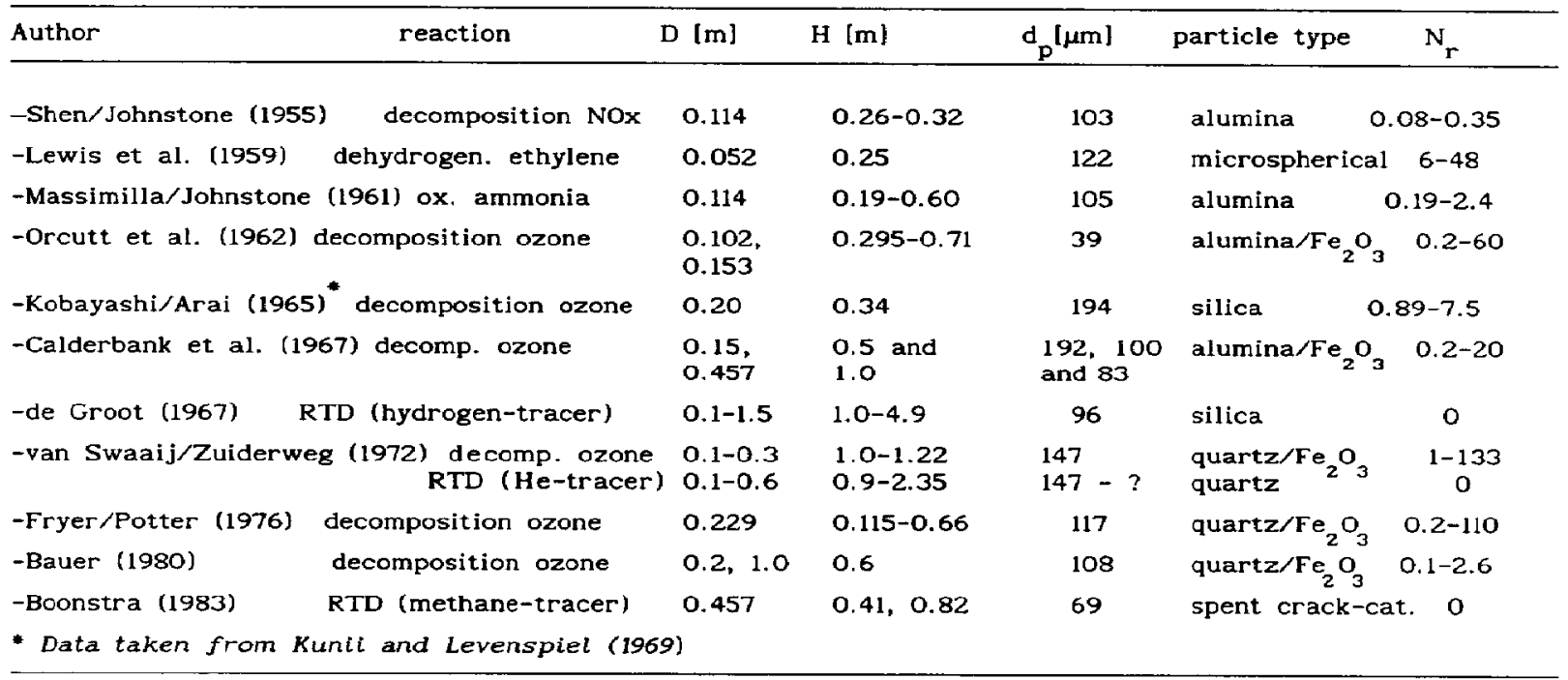

The chemical reaction experiments were all in steady state. $H_{\mathbf{k}}$ was calculated according to equation (1). The $H_{k}$ values from the non steady state (residence time distribution (RTD) experiments) were taken directly from the papers.

Statistical analyses did not give a practical relationship for $\mathbf{H}_{k}$ as a function of all the parameters, but some trends did show. Based on these statistical results we defined a Scaling parameter $S$ (with dimensions of lenght):

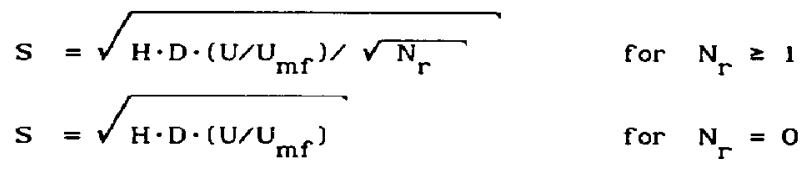

As was shown earlier too low a $\mathrm{N}_{\mathrm{r}}$ value gave some inaccuracies in calculating $\mathrm{H}_{\mathrm{k}}$. Based on the data 
A

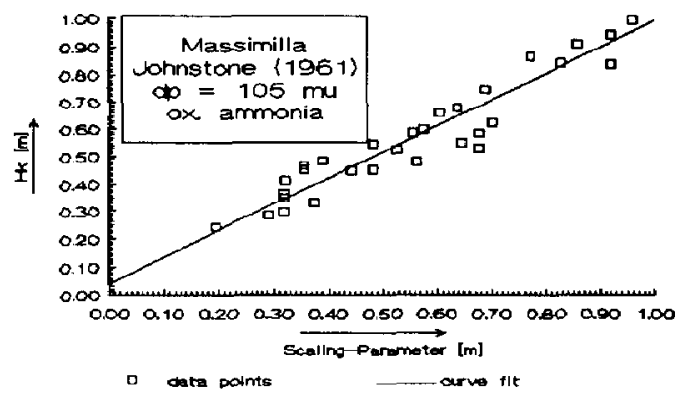

c

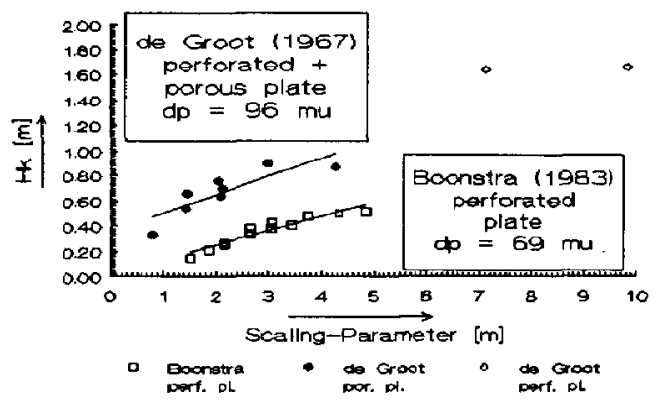

E

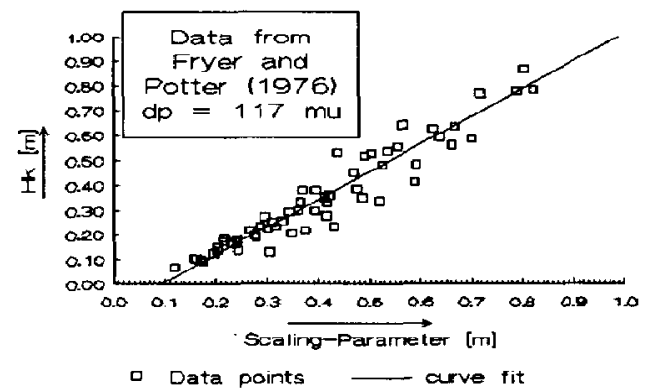

G

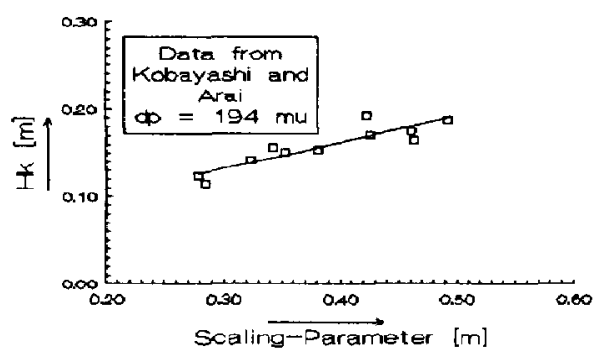

B

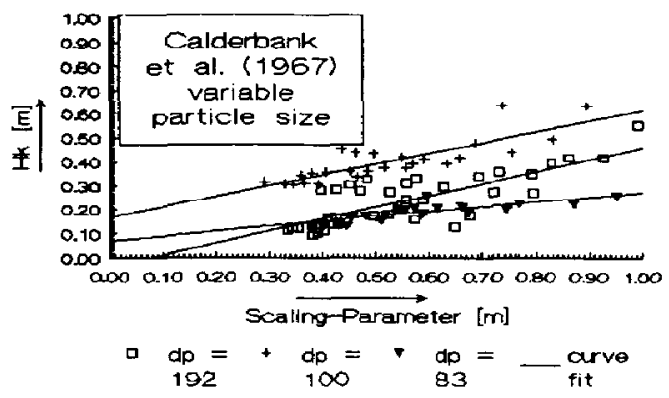

D

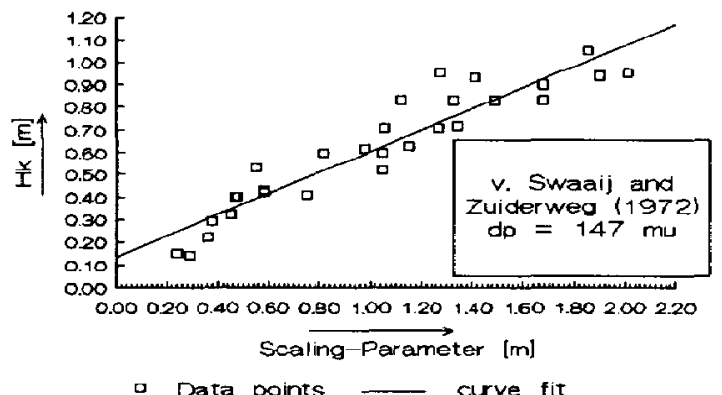

F

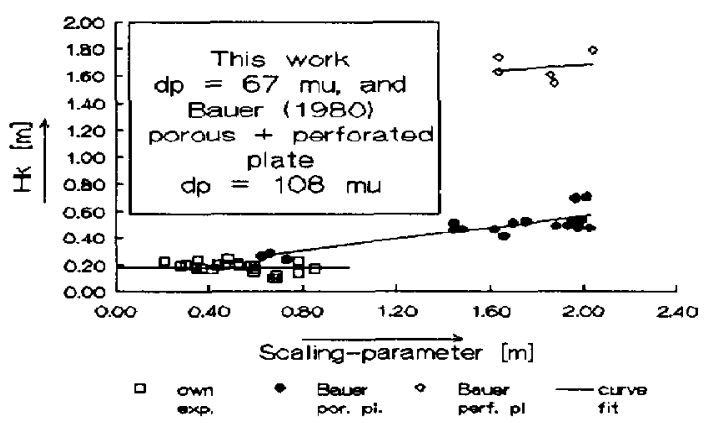

fig. $2 A-H$. Examples of $H_{k}$ versus Scaling parameter $S$. 
the minimum value $N_{r}=1$ was estimated. For the residence time distribution (RTD) measurements $\left(N_{I}=0\right)$, the $N_{r}$ value was simply left out. This implies that the $S$ values for reaction data are smaller than those calculated from RTD data.

\section{RESULTS AND DISCUSSION}

Plots of $H_{k}$ versus $S$ for the several experiments are given in fig. 2 . They show that, in all cases, $\mathbf{H}_{\mathbf{k}}$ could be correlated by:

$$
\mathbf{H}_{\mathbf{k}}=\mathrm{c}_{1}+\mathrm{c}_{2} \cdot \mathrm{s}
$$

In equation ( 3 ) $S$ and the constants $c_{1}$ and $c_{2}$ are dependent on the physical properties of the solid and gas phases and of the bed geometry. Equation (3) holds for all experiments, even for those where internals or perforated plates were used. Even for experiments with a wide range in $H$, $D$ and $U / U$ mf (table 2), $H_{k}$ could be correlated with $S$ by equation (3), indicating the wide applicability of the equation. Van Swaaij and Zuiderweg (1972) found that $H_{k} \sim H^{0.5} \cdot D^{0.42}$. We found virtually the same dependency by equations (2) and (3). Furthermore this factor makes it possible to compare experiments, whenever reactor geometry, reaction type, particle type and gas properties are the same.

Distributor (porous plate), catalyst (quartz sand) and reaction type (ozone decomposition) were the same for the experiments of Van Swaaij/Zuiderweg (1972), Bauer (1980) and ourselves. Plotting $\mathbf{H}_{k}$, from these experiments, as a function of $d_{p}$ with constant Scaling parameter $S$, confirmed our theory (see introduction) for A and small B powders: from fig. (3) it can be seen that $H_{k}$ indeed rises with increasing particle size. A relatively small $S$ value corresponds to a small reactor. Therefore figure (3) also shows that very small scale experiments are not suited for investigating the influence of $d_{p}$ on $H_{k}$. This was also found by de Groot (1967).

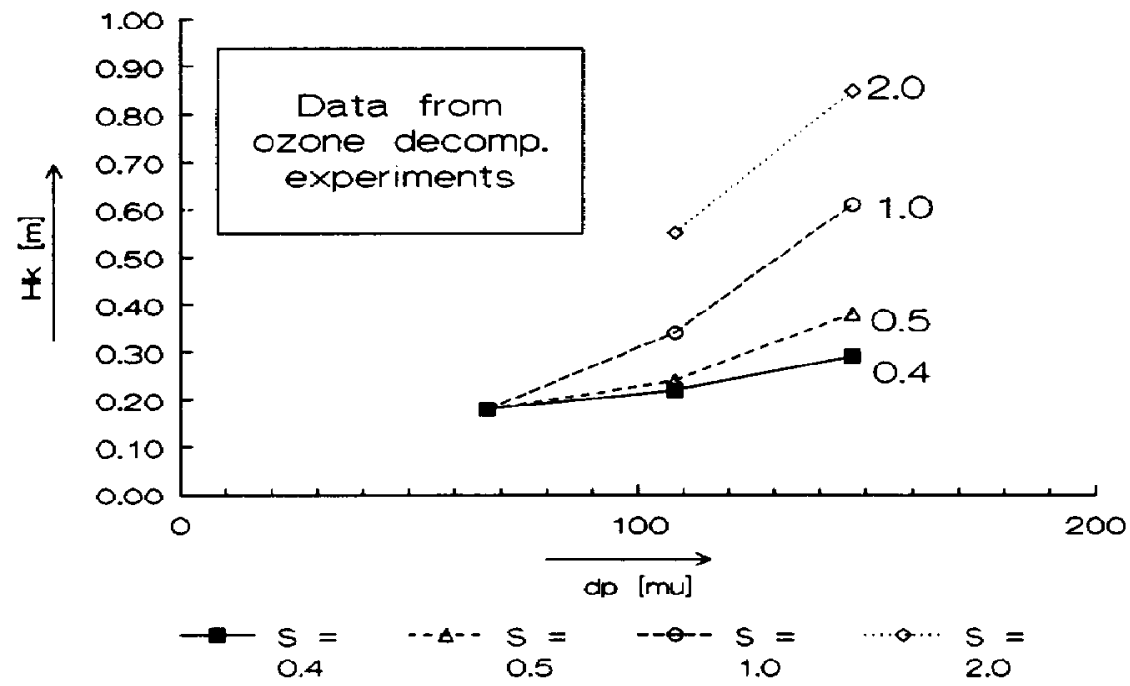

fig. 3. Helght of a mass transfer unit versus mean particle size, with constant Scaling parameter (from various authors, see text). 


\section{CONCLUSIONS}

${ }^{\prime} H_{k}$ values obtained from our experiments and a large number of literature data were analyzed. All these data could be correlated with the Scaling parameter $S$.

The constants $c_{1}$ and $c_{2}$ can be obtained from small scale experiments, as long as the scale is not too small. Therefore we believe that equations (2) and (3) can be useful in scale up of fluidized beds.

It was shown that, for A/B type powders, $\mathrm{H}_{k}$ rises with increasing particle size. This was also found from theoretical considerations. This shows that particle size selection is an important factor for improving the conversion in a fluidized bed.

Further experiments will be carried out to determine the influence of $d_{p}$ on $H_{k}$ for large particle systems.

\section{LIST OF SYMBOLS}

$c_{1}$ constant in eq. (3).

$c_{2} \quad$ constant in eq. (3).

$\mathrm{C}_{\mathrm{e}} \quad$ exit concentration.

$C_{\mathrm{f}}$ feed concentration.

$D$ bed diameter, $m$.

$d_{32}$ mean sieve particle size, $\mu \mathrm{m}$.

d particle size, $\mu \mathrm{m}$.

$\mathrm{D}_{\mathrm{g}}$ diffusion coefficient of (tracer)gas, $\mathrm{m}^{2} / \mathrm{s}$.

$\mathrm{H}$ bed height, $\mathrm{m}$.

$\mathrm{H}_{k} \quad$ height of a mass transfer unit, $m$.

$k_{r} \quad$ reaction rate constant, $\mathrm{m}^{3} /(\mathrm{kg} \cdot \mathrm{s})$.

$\mathrm{N}_{\text {. number }}$ of reaction units.

$N_{k} \quad$ number of mass transfer units.

$\mathrm{N}_{t}$ total number of units.

S Scaling parameter, $m$.

$\mathrm{U}$ superficial gas velocity, $\mathrm{m} / \mathrm{s}$.

$\mathrm{U}_{\mathrm{mf}}$ minimum fluidization velocity, $\mathrm{m} / \mathrm{s}$.

Greek

$\varepsilon_{\text {mf }}$ bed porosity at minimum fluidization.

$\mu_{\mathrm{g}}$ gas viscosity, $\mathrm{N} \cdot \mathrm{s} / \mathrm{m}^{2}$.

$\rho_{g} \quad$ gas density, $\mathrm{kg} / \mathrm{m}^{3}$.

$\rho_{\mathrm{p}} \quad$ particle density. $\mathrm{kg} / \mathrm{m}^{3}$.

\section{REFERENCES}

Bauer W. (1980), Einfluss der Gasverteilerkonstuktion auf Stoffaustausch- und Reactionsverhalten flacher Wirbelschichten, Ph. D. Thesis, Universität Erlangen.

Borodulya V.A., Buevich Yu. A. and Dikalenka V.I. (1981), Motion and mass transfer of bubbles in fluidized beds, J. Eng. Phys, 41, 1123. (Translated from: Inzh.- Fiz. Zh. 41, 678.)

Boonstra J. (1983), Internal report, University of Technology Eindhoven, Laboratory of Chemical Process Technology, June.

Calderbank P.H., Toor F.D. and Lancaster F.H. (1967), Reaction kinetics in gas fluidized catalyst bed (experimental), Proc. Int. Symp. Fluidization, p. 652, Netherlands Univ. Press, Amsterdam

Frye C.G., Lake W.C. and Eckstrom H.C. (1958), Gas-solid contacting with ozone decomposition reaction, A.I.Ch.E. Journal, 4 (4), 403.

Fryer C. and Potter O.E. (1976), Experimental investigation of model for fluidized bed catalytic reactors, A.I.Ch.E. Journal, 22 (1), 39. 
Geldart D. (1973). Types of Fluidization. Powder Technology, 7, 285.

Groot de J.H. (1967), Scaling up of fluidized bed reactors, Proc. Int. Symp. Flutdizatlon, p. 348, Netherlands Univ. Press, Amsterdam.

Kobayashi H, and Arai F. (1965), Kagaku Kogaku (Chem. Eng. Japan) 29, 885 .

Kunii D. and Levenspiel O. (1969), Fluldization Engtneerlng, John Wiley and Sons Inc., New York.

Lewis W.K., Gilliland E.R. and Glass W. (1959), Solid catalyzed reaction in a fluidized bed, A.I.Ch.E Journal, 5 (4), 419.

Massimilla L. and Johnstone H.F. (1961), Reaction kinetics in fluidized beds, Chem. Eng. Sct., 16, $105-112$

Orcutt J.C., Davidson J.F. and Pigford R.L. (1962), Reaction time distribution in fluidized catalytic reactors, Chem. Eng., Prog. Symp. Serles, 58 (38), 1.

Perry R.H. and Chilton C.H. (1973), Chemical Engineers' Handbook 5th ed., Mc. Graw-Hill Book Company.

Shen C.Y. and Johnstone H.F. (1955), Gas solid contact in fluidized beds, A.I.Ch.E. Journal, 1 (3), 349

Sit S.P. and Grace J.R. (1978), Interphase mass transfer in aggregative fluidized beds, Chem. Eng. Sct, 33, $1115-1122$.

Van Deemter J.J. (1961), Mixing and contacting in gas-solid fluidized beds, Chem. Eng. Sct., 13, 143-154.

Van L.are C.E.J. (1990), Ph. D. Thesis, Univ. Techn. Eindhoven, to be published

Van Swaaij W.P.M. and Zuiderweg F.J. (1972), Investigation of ozone decomposition in fluidized beds on the basis of a two phase model, Chem. React. Eng., Proc. Eur. Symp. 5th, B9-25.

Wen C.Y. and Yu Y.H. (1966), Mechanics of fluidization, Chem. Eng,, Prog. Symp. Sertes, 62 , 100. 